\title{
PALM OIL MILL EFFLUENT AS ALGAE CULTIVATION MEDIUM FOR BIODIESEL PRODUCTION
}

\author{
NUR AZREENA IDRIS*; SOH KHEANG LOH*; HARRISON LIK NANG LAU*; TAN CHENG YAU**; \\ EMINOUR MUZALINA MUSTAFA ${ }^{*}$ VEJEYSRI VELLO** and PHANG SIEW MOI**
}

\begin{abstract}
Palm oil mill effluent (POME) - a wastewater from the palm oil milling process is beneficial as a low-cost carbon source for microalgae growth. This does not only help clean the wastewater but also reduce the algal cultivation cost. In this study, the growth rate, biomass productivity and biochemical compositions of Chlorella sp. grown in diluted POME under outdoor conditions using a 200-ml capacity high rate alga pond (HRAP) and two closed photobioreactors (PBR) i.e. annular and flat panel were assessed. The strain, Chlorella sp. grown on 5\% of POME in a flat panel PBR exhibited the highest specific growth rate of 0.5 per day and biomass productivity (137.5 $\mathrm{mg} \mathrm{litre}^{-1} \mathrm{per}$ day) followed by those in HRAP and annular PBR. Additionally, a good growth of Chlorella sp. in POME could sufficiently utilise the nutrients of POME such as phosphate $\left(\mathrm{PO}_{4}\right)$, nitrate $\left(\mathrm{NO}_{3}\right)$, nitrite $\left(\mathrm{NO}_{2}\right)$ and organic substances. The extracted algal oil from the diluted POME culture (5\%) showed decrease in the saturated fatty acids and an increase in the polyunsaturated fatty acids compared to those cultured in the standard Bold's Basal Medium (BBM). The biochemical compositions of the algae grown in the flat panel PBR were the highest with lipid, protein and carbohydrate productivity of $17.9 \mathrm{mg}$ litre $\mathrm{H}^{-1}$ per day, $34.7 \mathrm{mg} \mathrm{litre}^{-1}$ per day and $21.4 \mathrm{mg}$ litre-1 per day, respectively. The microalgae cultivation in diluted POME had not only shown good potential as a biodiesel feedstock based on the fatty acids profile but also the ability to reduce some pollutants e.g. $\mathrm{PO}_{4}, \mathrm{NO}_{3}, \mathrm{NO}_{2}$ and chemical oxygen demand (COD) in the biological wastewater treatment.
\end{abstract}

Keywords: wastewater treatment, photobioreactors, biomass productivity, specific growth rate, COD reduction.

Date received: 21 June 2017; Sent for revision: 3 July 2017; Received in final form: 21 September 2017; Accepted: 10 January 2018

\section{INTRODUCTION}

In Malaysia, the palm oil industry is an important economic force contributing significantly to the

\footnotetext{
Malaysian Palm Oil Board

6 Persiaran Institusi, Bandar Baru Bangi,

43000 Kajang, Selangor, Malaysia.

E-mail: lohsk@mpob.gov.my

** Institute of Ocean and Earth Sciences, Universiti Malaya, 50603 Kuala Lumpur, Malaysia.

* Universiti Malaysia Terengganu, T145,

21300 Kuala Terengganu, Terengganu, Malaysia.
}

nation's revenue streams. The industry involves a planted area of 5.74 million hectares and a processing capacity of 453 palm oil mills. In 2016, the crude palm oil (CPO) production was 17.3 million tonnes (MPOB, 2016). Malaysia is one of the largest $\mathrm{CPO}$ producers and exporters accounting for $12 \%$ of the world's oils and fats production and $27 \%$ of world export (MPOC, 2013). Generally, the palm oil extraction process requires a lot of water and consequently generates large amounts of palm oil mill effluent (POME) (Wang et al., 2015; Loh et al., 2013). For each tonne of CPO, 5-7.5 $t$ of water are 
required and more than $50 \%$ of the water ends up as wastewater known as POME.

POME is a thick brownish liquid that contains high level of suspended solids, oil and greases with chemical oxygen demand (COD) and biological oxygen demand (COD) (Hancsók et al., 2007) that can pollute a water source if discharged untreated (Loh et al., 2013). Conventionally, it is treated in a series of anaerobic and aerobic ponds that require more than 100 days of treatment. This type of treatment system is not able to meet the required discharge limits. The high content of organic materials and nutrients in POME makes it possible as a low-cost substrate for cultivating microalgae. Microalgae utilises the organic carbon material and nutrients in POME for its growth, thus removing some of these contaminant sources of pollution (Azmi and Yunos, 2014). Microalgae can survive in various types of wastewater. They are able to perform different types of metabolism i.e. autotrophic, heterotrophic, mixotrophic and photoheterotrophic depending on the surrounding environment (Brennan and Owende, 2010).

Additionally, microalgae offers an interesting alternative feedstock for the production of biofuels. Microalgae has a high total biomass yield and utilises lower land areas which are unsuitable for food production. It also has the potential to utilise any emitted $\mathrm{CO}_{2}$ for photosynthesis which then offers a carbon neutral biofuel (Chen et al., 2011). However, the microalgae poses a sensitive characteristic i.e. vulnerable to the changes in culture conditions which might become a major drawback in the production of algal oil that is capable of meeting the biodiesel standards. Other environmental factors such as climatic conditions especially temperature and culture management techniques may influence the up-scaling of microalgae for mass cultivation in outdoor or closed photobioreator (PBR) (MorenoGarcia et al., 2017; Mata et al., 2010; Idris et al., 2017).

Chlorella, one of the most studied microalgae, is commercially cultivated by more than 70 companies worldwide mainly as dietary supplements and nutraceuticals (Guccione et al., 2014). It is commercially grown under photoautotrophic conditions in open ponds (both raceway and circular), or heterotrophically in fermenters (Guccione et al., 2014). However, most Chlorella strains can grow mixotrophically in short doubling times and simple growth requirements (Rai et al., 2014). Previous studies using Chlorella strains cultured in several types of PBR have demonstrated a high lipid productivity up to $330 \mathrm{mg}$ litre $^{-1}$ per day due to a high biomass production rate (Pribyl et al., 2012; Idris et al., 2017). This indicates that most Chlorella strains are able to produce biomass in high quantity. Quality feedstock from microalgae for conversion to biodiesel demands not only high biomass content and lipid productivity but also a suitable fatty acid compositions (FAC). To date, high production cost is a serious setback for the production of biofuel from microalgae. Among the potential microalgae species, Chlorella is of major interest for biofuels owing to its ability to accumulate large amounts of lipids under stress (Idris et al., 2017). Thus, this study aimed to compare the growth of Chlorella UMACC 283 in different cultivation system using POMEenriched medium and assess the resulting algal oil as biodiesel feedstocks.

\section{MATERIALS AND METHODS}

\section{POME}

POME was collected from the raw and anaerobic ponds from Tennamaram Estate Processing Mill and characterised for $\mathrm{pH}, \mathrm{COD}$, ammoniacal-N, phosphate-P, nitrate, nitrite, total solid (TS), total suspended solid (TSS) and total volatile solid (TVS). Algae from POME were isolated and purified for further characterisation.

\section{Cultivation Condition}

The microalgae, Chlorella (UMACC 283) from the University of Malaya culture collection was cultured in $6.25 \%(\mathrm{v} / \mathrm{v}), 12.5 \%(\mathrm{v} / \mathrm{v}), 25.0 \%(\mathrm{v} / \mathrm{v})$ and $50.0 \%(\mathrm{v} / \mathrm{v})$ POME in 600-ml flasks at laboratory conditions as mentioned by Vello et al. (2013), while that of $5.0 \%(\mathrm{v} / \mathrm{v})$ POME cultivation at outdoor conditions was chosen based on the previous studies (Idris et al., 2017; Tan et al., 2016) showing optimum values as follows: chlorophyll a (Chl-a) concentration (27.4 mg litre $\left.{ }^{-1}\right)$, dry weight (1296.7 $\mathrm{mg}$ litre $^{-1}$ ) and specific growth rate of 0.84 per day (Figure 1). Three types of outdoor PBR were used namely high rate algal ponds (HRAP), annular and flat panel PBR (Figure 2). Bold's Basal Medium (BBM) was used as a control. For the outdoor cultivation, the algal culture was harvested and replaced with fresh culture medium every two days. Samples were also collected for growth analysis by assessing the optical density $\left(\mathrm{OD}_{620}\right)$, Chl-a, carotene content and biochemical compositions i.e. protein, carbohydrate and lipid contents (Vello et al., 2013).

\section{Growth Monitoring}

The microalgae growth monitoring was conducted based on $\mathrm{OD}_{620}$ and Chl-a concentration. The microalgae was extracted overnight with acetone, filtered and homogenised using $0.45 \mu \mathrm{m}$ filters (Whatman Gf/C). The Chl-a concentration was determined at 665, 645 and $630 \mathrm{~nm}$ using a UVvis spectrophotometer (Shimadzu UV 1700, Japan) 


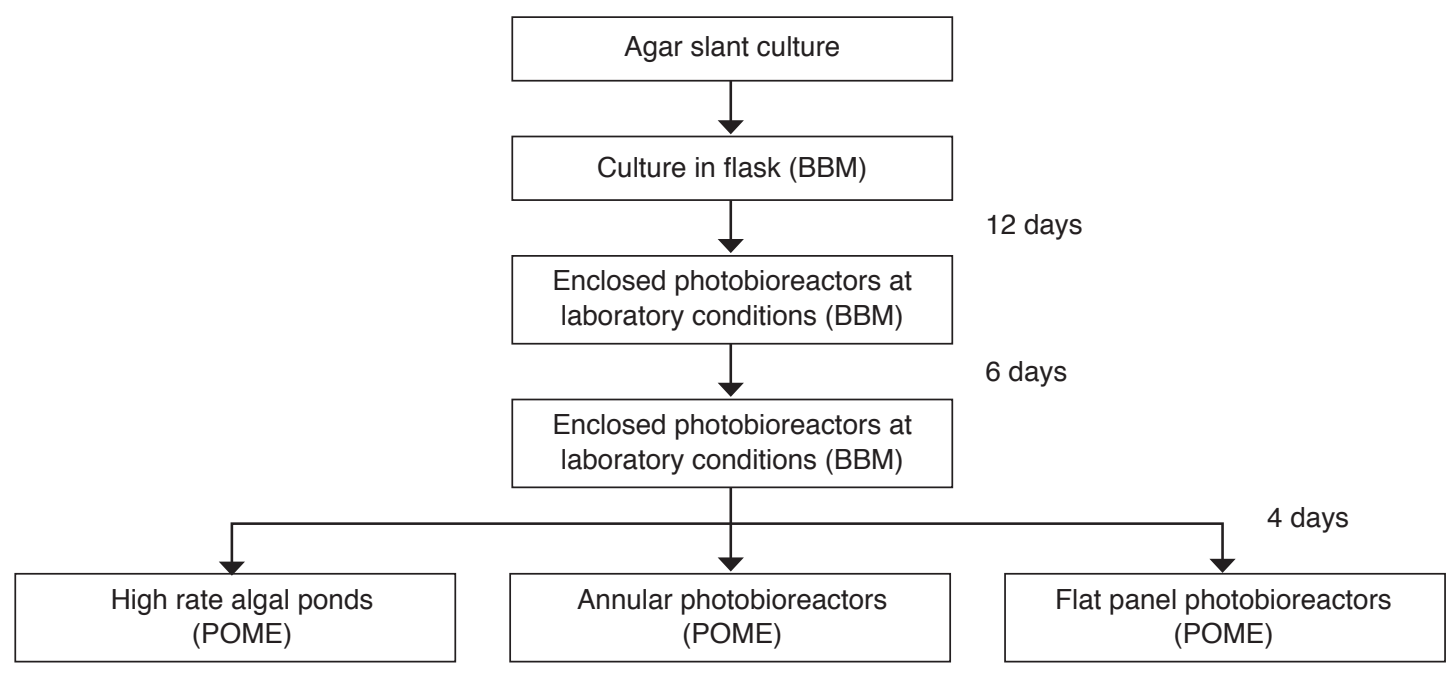

Figure 1. Cultivation condition for Chlorella UMACC 283 using 5\% palm oil mill effluent (POME).

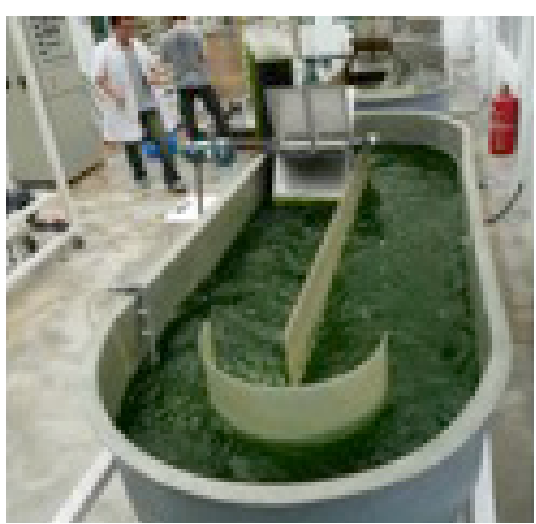

High rate algal pond (HRAP)

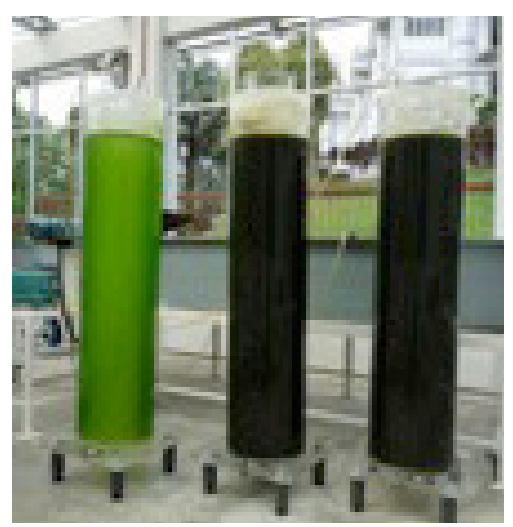

Annual PBR

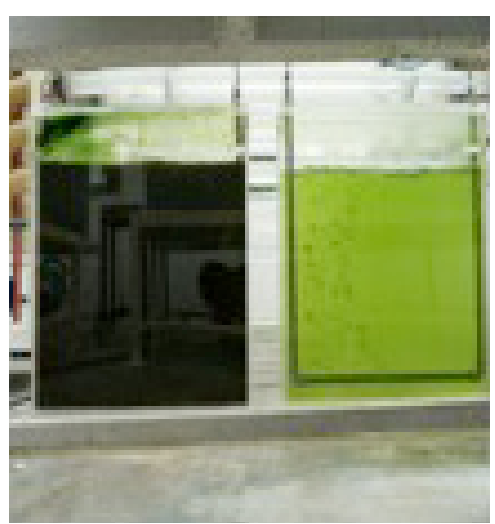

Flat panel PBR

Figure 2. Different outdoor photobioreactor (PBR) for Chlorella UMACC 283.

based on Equation (1) by Strickland and Parson (1972).

Chl- $\mathrm{a}=\mathrm{A} \times$ volume of acetone in $\mathrm{ml} /$ volume of sample in $\mathrm{ml}$

where $\mathrm{A}($ Absorbance $)=11.6\left(\mathrm{OD}_{665}\right)-1.31\left(\mathrm{OD}_{645}\right)$

$-0.14\left(\mathrm{OD}_{630}\right)$ Equation (1)

The specific growth rate ( $\mu$, per day) based on Chl-a concentration was calculated based on Equation (2):

$$
\mu\left(\text { day }^{-1}\right)=\operatorname{Ln}\left(N_{2} / N_{1}\right) /\left(t_{2}-t_{1}\right)
$$

Equation (2)

where $\mathrm{N}_{2}$ is chlorophyll content $\left(\mathrm{mg} \mathrm{ml}^{-1}\right)$ at $\mathrm{t}_{2}$ $N_{1}$ is chlorophyll content $\left(\mathrm{mg} \mathrm{ml}^{-1}\right)$ at $\mathrm{t}_{1}$, and $\mathrm{t}_{1}, \mathrm{t}_{2}$ are times within the exponential phase.

Cells were harvested between late exponential to early stationary phase to determine dry weight, lipid content and fatty acid compositions (FAC) (Vello et al., 2013).

\section{Determination of Biomass and Biochemical Composition}

Solvent such as n-hexane was purchased from Sigma Aldrich (St. Louis, MO, USA). Algal biomass cultured in PBR was harvested via centrifugation, then freeze-dried at $-51^{\circ} \mathrm{C}$ and $10 \times 10^{-4} \mathrm{~atm}$. The dried biomass was extracted in $\mathrm{n}$-hexane using soxhlet extractor until the hexane was colourless and the lipid content determined via gravimetric method (Elmoraghy and Farag, 2014). The hexane was removed by rotary evaporator leaving the orange lipid as crude algal oil.

\section{FAC Analysis}

The lipids were transesterified in $1.2 \%(\mathrm{w} / \mathrm{v})$ $\mathrm{HCl}$ in $\mathrm{MeOH}$, toluene, and water $\left(100^{\circ} \mathrm{C}, 1 \mathrm{hr}\right)$ (Ichihara and Fukubayashi, 2010). The extracted fatty acid methyl esters (FAME) were stored in an inert atmosphere $\left(\mathrm{N}_{2}\right)$ in a freezer at $-18^{\circ} \mathrm{C}$. The 
composition of FAME in the sample $(1 \mu \mathrm{l})$ was analysed using the Agilent 7820A GC equipped with a capillary column (SLB-IL100, $30 \mathrm{~m} \times 0.25 \mathrm{~mm}$ $\times 0.20 \mu \mathrm{m}$, Supelco, USA) and a flame ionisation detector with temperatures of the injector and detector set at $250^{\circ} \mathrm{C}$ and $260^{\circ} \mathrm{C}$, respectively. The following thermal ease of $5^{\circ} \mathrm{C} \mathrm{min}$ min $^{-1}$ unt it reached $260^{\circ} \mathrm{C}$. Helium was used as carrier gas at 4.41

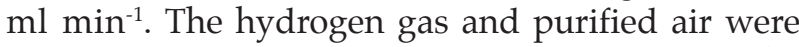
flowed at 30 and $450 \mathrm{ml} \mathrm{min}{ }^{-1}$, respectively. The quantification of FAME was performed in triplicate by adding an internal standard (C7:0 Sigma ${ }^{\circledR}$, USA).

\section{RESULTS AND DISCUSSION}

The characteristic of POME (Table 1) clearly showed that POME contained high $\mathrm{N}$ and $\mathrm{P}$ nutrients that are of interest and potential for microalgae growth. These nutrients could support photosynthesis reaction to produce algal biomass consisting of lipid, protein and carbohydrate for conversion into valuable products e.g. biofuel, bioethanol or feed supplement (Hadiyanto et al., 2012; Hadiyanto and

TABLE 1. CHARACTERISTICS OF PALM OIL MILL EFFLUENT (POME) USED IN THIS STUDY

\begin{tabular}{lc}
\hline Parameter $^{*}$ & $\begin{array}{c}\text { Concentration }^{\left(\text {mg litre }^{-1}\right)} \\
\text { pH }\end{array}$ \\
Chemical oxygen demand (COD) & $4.9 \pm 0.1$ \\
Total solid & $51233 \pm 246$ \\
Total suspended solids & $55356 \pm 257$ \\
Chlorophyll a & $35648 \pm 214$ \\
Carotenoid & $0.19 \pm 0.01$ \\
Ammoniacal nitrogen & $0.08 \pm 0.01$ \\
Nitrate & $26 \pm 1$ \\
Nitrite & $753 \pm 15$ \\
Phosphate & $3.5 \pm 0.3$ \\
\hline
\end{tabular}

Note: * Units in mg litre-1 except for $\mathrm{pH}$.
Nur, 2012). According to Griffiths and Harrison (2009), a large-scale cultivation of microalgae for biofuel production is dependent on growth rate and oil content (in \% dwb). As POME is rich in COD, $\mathrm{BOD}, \mathrm{N}$ and $\mathrm{P}$, it has been used in culturing different microalgae (Kamyab et al., 2015; Vairappan and Yen, 2008).

Microalgae cultivated in different POME concentration showed higher biomass and lipid content (440 mg litre ${ }^{-1}$ to $627 \mathrm{mg}$ litre $^{-1}$ and $15.9 \%$ to $30.9 \%$, dwb) compared to that in standard medium (BBM) with $257 \mathrm{mg}^{\text {litre }} \mathrm{I}^{-1}$ of biomass and $23.8 \%$ (dwb) lipid content (Table 2). The POME concentration that gave the highest growth rate of 0.32 per day for Chlorella UMACC 283 was $12.5 \%$, followed by that in $6.25 \%$ POME at laboratory scale. POME contains a variety of biocompounds that can stimulate microalgal growth (Nwuche, 2014). Besides, POME is also high in inorganic components such as nitrate $\left(\mathrm{NO}_{3}\right)$, and phosphate $\left(\mathrm{PO}_{4}\right)$ that are easily accessible as nutrients in microalgae cultivation (Vairappan and Yen, 2008). It is undeniable that lipid productivity is an important factor in microalgae species selection for biodiesel production (Huerlimann et al., 2010). It correlates with biomass productivity and can be a useful indicator to select the feedstock for biodiesel production (Vello et al., 2013).

The higher the concentration of POME, the lower the growth of Chlorella due to inadequate light penetration due to the darker colour of POME. The problematic colour appearance in POME may probably caused by the present of tannic acid (Hadiyanto and Nur, 2012). Moreover, algae cultured in highly concentrated POME took a longer time to reach the stationary phase and generated lower biomass due to longer lag phase (Nur and Hadiyanto, 2013). It was found also that separation of the algal biomass from POME was difficult when higher POME concentrations were employed. Besides, the lipid content was found the highest in the medium with $12.5 \%$ POME.

TABLE 2. GROWTH OF Chlorella UMACC 283 IN DIFFERENT CONCENTRATION OF PALM OIL MILL EFFLUENT (POME) IN LABORATORY CONDITIONS

\begin{tabular}{lccccc}
\hline Treatment & $\begin{array}{c}\text { Biomass } \\
\left(\mathbf{m g ~ l i t r e}^{-1}\right)\end{array}$ & $\begin{array}{c}\text { Lipid content } \\
(\%)\end{array}$ & $\begin{array}{c}\text { Specific growth } \\
\text { rate (per day) }\end{array}$ & $\begin{array}{c}\text { Biomass } \\
\text { productivity } \\
\left(\text { mg litre }^{-1} \text { per day) }\right.\end{array}$ & $\begin{array}{c}\text { Lipid } \\
\text { productivity } \\
\text { (mg litre } \text { per day })^{-1}\end{array}$ \\
\hline $\begin{array}{l}\text { BBM } \\
\text { (control) }\end{array}$ & $256.7 \pm 35.1$ & $23.8 \pm 3.9$ & $0.28 \pm 0.06$ & $10.4 \pm 2.2$ & $0.32 \pm 0.13$ \\
$\begin{array}{l}6.25 \% \\
\text { POME }\end{array}$ & $440.0 \pm 36.1$ & $26.8 \pm 5.6$ & $0.31 \pm 0.03$ & $19.5 \pm 3.1$ & $0.71 \pm 0.28$ \\
$\begin{array}{l}12.5 \% \\
\text { POME }\end{array}$ & $590.0 \pm 26.5$ & $30.9 \pm 10.1$ & $0.32 \pm 0.06$ & $27.1 \pm 1.4$ & $1.00 \pm 0.34$ \\
$\begin{array}{l}25 \% \\
\text { POME }\end{array}$ & $533.3 \pm 62.6$ & $15.9 \pm 1.3$ & $0.07 \pm 0.08$ & $16.1 \pm 10.1$ & $0.34 \pm 0.17$ \\
$\begin{array}{l}50 \% \\
\text { POME }\end{array}$ & $626.7 \pm 63.9$ & $20.9 \pm 3.9$ & $0.19 \pm 0.06$ & $11.7 \pm 7.1$ & $0.13 \pm 0.29$ \\
\hline
\end{tabular}

Note: BBM - Bold's Basal Medium. 
Nutrient removal is important in wastewater treatment because rich nutrient streams may resulted in eutrophication and phosphorus accumulation (Dalrymple et al., 2013). Cultivation of Chlorella UMACC 283 in 12.5\% POME concentration showed potential in pollution reduction (Figure 3) as most of the 'polluting nutrients' e.g. $\mathrm{PO}_{4}, \mathrm{NO}_{3}$, $\mathrm{NO}_{2}$ and organic substances in the form of COD were successfully reduced with removal efficiencies of $59 \%, 29 \%, 40 \%$ and $55 \%$, respectively. This may to certain extent help in improving the quality of wastewater in use.

In cultivating Chlorella UMACC 283 at outdoor PBR using 5\% POME, the exponential growth phase was achieved in Day 3. The growth of this Chlorella in Day 4 is shown (Figure 4). Basically, POME medium showed better carbon source for Chlorella UMACC 283 growth than the BBM. The highest biomass production was obtained when Chlorella UMACC 283 was cultured using 5\% POME in annular PBR (2.27 $\mathrm{g} \mathrm{litre}^{-1}$ ) followed by HRAP (1.06 g litre $^{-1}$ ) (Table 3) and flat panel PBR $\left(0.87 \mathrm{~g} \mathrm{litre}^{-1}\right)$, respectively. However, the growth of Chlorella UMACC 283 in flat panel PBR showed the highest specific growth rate ( 0.53 per day) and Chl-a (7.62 mg litre $^{-1}$ per day). In addition, Badar et al. (2017) performed a study in a laboratory scale PBR at room temperature under continuous illumination for 14 days and $10 \% \mathrm{v} / \mathrm{v}$ POME discovered that the specific growth rate for Chlorella sorokiniana UKM3, Coelastrella UKM4 and Chlorella UMACC324 were 0.20 per day, 0.22 per day and 0.19 per day respectively. The growth of Chlorella UMACC 283 in this study was much higher. The variation of growth rates is usually related to the algal growth conditions and requirements (Juneja et al., 2013).

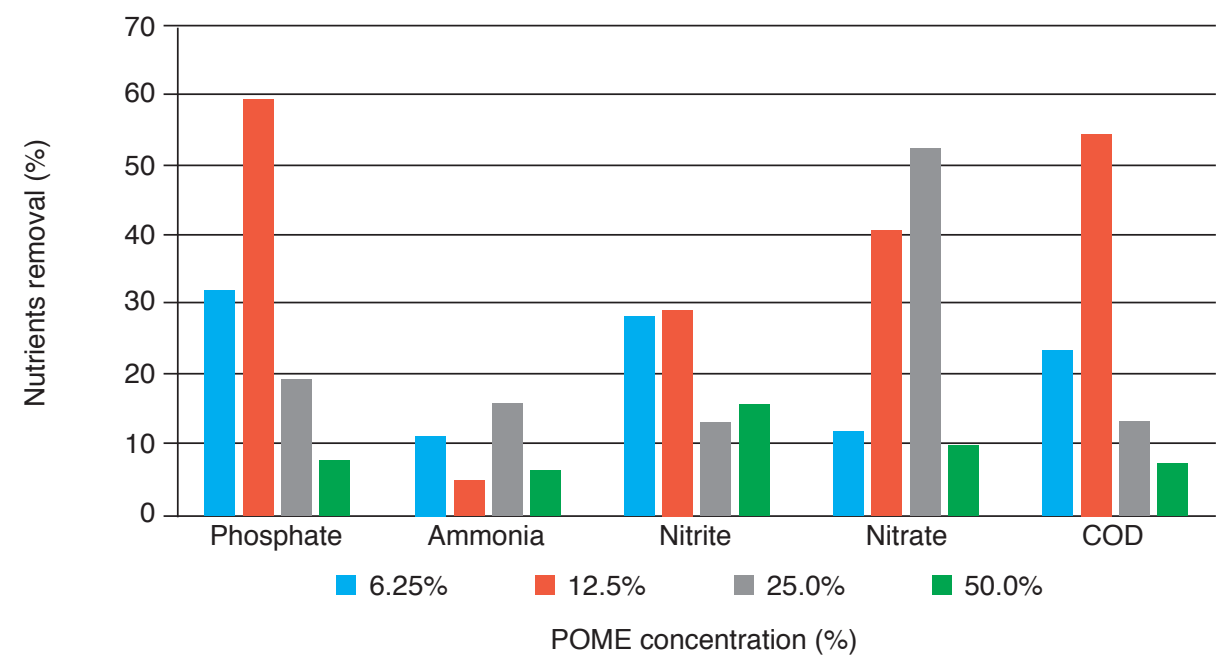

Note: COD - chemical oxygen demand.

Figure 3. Nutrients removal efficiencies of Chlorella UMACC 283 cultured in palm oil mill effluent (POME).

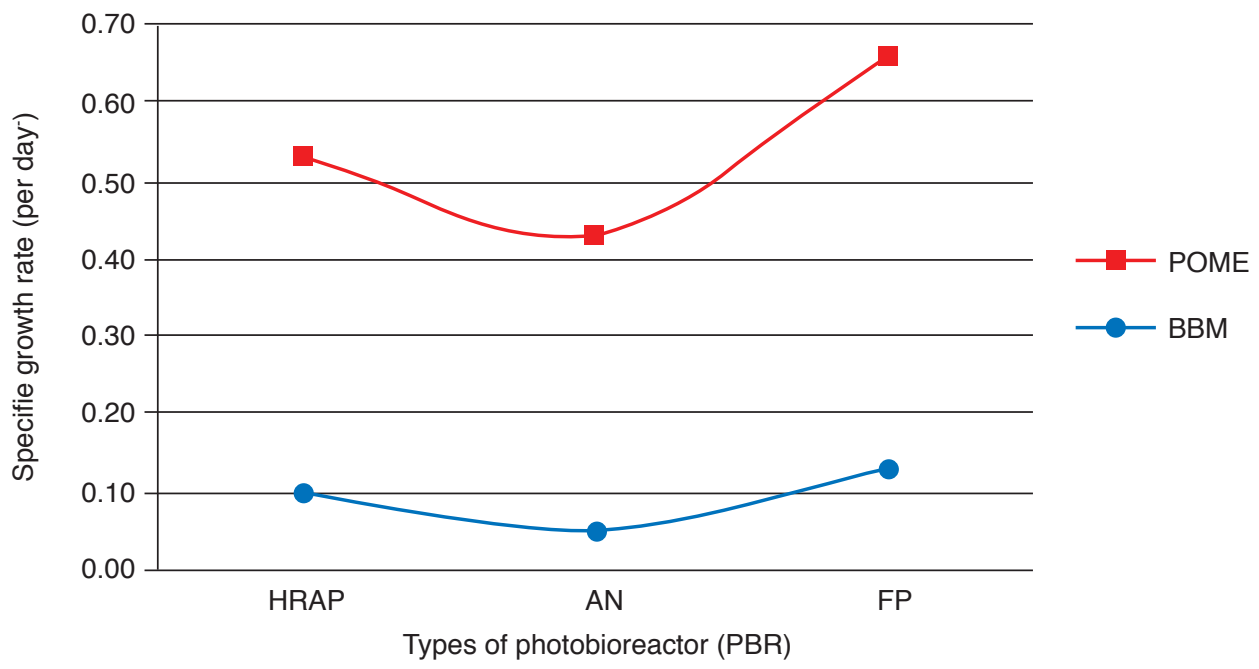

Note: HRAP - high rate algal pond. BBM - Bold's Basal Medium.

AN - annular.

PP - flat panel.

Figure 4. Specific growth rate of Chlorella UMACC 283 in 5\% palm oil mill effluent (POME) via outdoor cultivation. 
For biochemical study, the highest productivities for carbohydrate (21.4 mg litre ${ }^{-1}$ per day) protein (34.7 mg litre ${ }^{-1}$ per day) and lipid (17.9 mg litre ${ }^{-1}$ per day) were obtained from flat panel PBR in $5 \%$ POME (Table 4). Hence, flat panel PBR was found the highest performing system in culturing Chlorella UMACC 283 in 5\% POME. The biochemical productivities from HRAP also were not bad, but with a reduced $47 \%$ in carbohydrate (11.4 mg litre li $^{-1}$ per day), 37\% in protein (21.8 $\mathrm{mg}$ litre $^{-1}$ per day) and 30\% in lipid (12.5 mg litre-1 per day). Besides, although the HRAP open pond system showed good biochemical compositions, it has several limitation such as high contamination risk and space requirement (Narala et al., 2016) making it less suitable for large scale production.

The lipid and biomass productivity during microalgae cultivation should be assessed appropriately to facilitate obtaining a suitable species for biodiesel production (Vello et al., 2013). The choice of utilising algal biomass depends on its constituents and may impart the economic of biodiesel production (Hempel et al., 2012) e.g. Chlorella and Spirulina (Arthrospira) contain high amounts of protein (50\% to 60\%, dwb) that favour coproduction of food, feed supplements and fertiliser (Lammens et al., 2012). Chlorella was also reported to accumulate high amount of carbohydrate i.e. $>40 \%, \mathrm{dwb}$ and has potential for bioethanol and biogas production (Lee et al., 2015). This should be investigated in-depth to reduce the overall cost of production to make microalgae an alternative in wastewater treatment more feasible.

The FAC profiles of the lipid extracts of Chlorella UMACC 283 (Table 5) grown in 5\% POME were compared with those grown in BBM. Both cultivation medium showed that the palmitic acid (C16:0), stearic acid (C18:0), oleic acid (C18:1), linoleic acid (C18:2) and linolenic acid (C18:3) were the predominant fatty acids in the microalgae grown. The highest amount of C16:0 was obtained when the microalgae was cultivated in annular PBR followed by flat panel PBR while for C18:0 by HRAP, all in BBM. Cultivation using 5\% POME showed mainly the changes in unsaturated fatty acid compositions.

The algal oil from all the different cultivation systems exhibited more saturated fatty acids than the unsaturated ones (Table 6). Cultivation in diluted POME $(5 \%)$ could reduce the saturation portion of fatty acids while that of unsaturation increased slightly. In BBM cultivation, the saturation level of the algal oil varied and could not be predicted. Indepth study is required to confirm if the different culture system using POME had indeed influenced

TABLE 3. THE GROWTH STUDY OF Chlorella UMACC 283 IN 5\% PALM OIL MILL EFFLUENT (POME) VIA OUTDOOR CULTIVATION

\begin{tabular}{clccc}
\hline Day & System & $\begin{array}{c}\text { Biomass content } \\
(\mathbf{d w b})\left(\mathbf{g ~ l i t r e}^{-1}\right)\end{array}$ & $\begin{array}{c}\text { Chlorophyll a } \\
\left(\mathbf{m g ~ l i t r e}^{-1}\right)\end{array}$ & $\begin{array}{c}\text { Specific growth } \\
\text { rate (per day) }\end{array}$ \\
\hline 0 (control) & BBM & $0.07 \pm 0.01$ & $1.5 \pm 0.03$ & - \\
0 (control) & POME & $0.81 \pm 0.01$ & $1.6 \pm 0.03$ & - \\
4 & HRAP (BBM) & $0.13 \pm 0.00$ & $1.67 \pm 0.05$ & 0.10 \\
4 & HRAP (POME) & $1.06 \pm 0.04$ & $5.57 \pm 0.03$ & 0.43 \\
4 & AN (BBM) & $0.12 \pm 0.00$ & $1.30 \pm 0.19$ & 0.05 \\
4 & AN (POME) & $2.27 \pm 0.06$ & $4.68 \pm 0.42$ & 0.38 \\
4 & FP (BBM) & $0.11 \pm 0.00$ & $2.08 \pm 0.09$ & 0.13 \\
4 & FP (POME) & $0.87 \pm 0.01$ & $7.62 \pm 0.5$ & 0.53 \\
\hline
\end{tabular}

Note: dwb - dry weight basis. BBM - Bold's Basal Medium. HRAP - high rate algal pond. AN - annular. FP- flat panel.

TABLE 4. THE BIOCHEMICAL COMPOSITIONS OF Chlorella UMACC 283 IN 5\% PALM OIL MILL EFFLUENT (POME) VIA OUTDOOR CULTIVATION

\begin{tabular}{|c|c|c|c|c|}
\hline Day & System & $\begin{array}{c}\text { Carbohydrate } \\
\text { productivity } \\
\left(\mathrm{mg} \text { litre }^{-1} \text { per day) }\right.\end{array}$ & $\begin{array}{c}\text { Protein } \\
\text { productivity } \\
\left(\mathrm{mg} \text { litre }^{-1} \text { per day) }\right.\end{array}$ & $\begin{array}{c}\text { Lipid } \\
\text { productivity } \\
\left(\mathrm{mg} \text { litre }^{-1} \text { per day }\right)\end{array}$ \\
\hline 4 & HRAP (BBM) & 2.29 & 2.44 & 2.94 \\
\hline 4 & HRAP (POME) & 11.4 & 21.8 & 12.5 \\
\hline 4 & AN (BBM) & 0.83 & 1.25 & 1.69 \\
\hline 4 & AN (POME) & 10.4 & 9.17 & 6.56 \\
\hline 4 & $\mathrm{FP}(\mathrm{BBM})$ & 3.03 & 4.29 & 5.22 \\
\hline 4 & FP (POME) & 21.4 & 34.7 & 17.9 \\
\hline
\end{tabular}

Note: BBM- Bold's Basal Medium. HRAP- high rate algal pond. AN- annular. FP- flat panel. 
TABLE 6. SUMMARY OF SATURATED AND UNSATURATED FATTY ACID OF Chlorella UMACC 283 IN 5\% PALM OIL MILL EFFLUENT (POME) AT DIFFERENT CULTIVATION SYSTEM

\begin{tabular}{lcc}
\hline System & $\begin{array}{c}\text { Saturated } \\
\text { fatty acid } \\
\mathbf{( w t} \%)\end{array}$ & $\begin{array}{c}\text { Unsaturated } \\
\text { fatty acid } \\
\text { (wt\%) }\end{array}$ \\
\hline HRAP (BBM) & 81.1 & 17.9 \\
HRAP (POME) & 64.2 & 35.8 \\
AN (BBM) & 64.8 & 35.2 \\
AN (POME) & 63.6 & 36.4 \\
FP (BBM) & 77.7 & 22.3 \\
FP (POME) & 70.1 & 30.0 \\
\hline
\end{tabular}

Note: BBM - Bold's Basal Medium. HRAP - high rate algal pond. AN - annular. FP - flat panel.

the production of compositional algal lipid suitable as biodiesel feedstock.

In all cases, the high saturated fatty acids of the algal oil were indicator of a good quality biodiesel with high cetane number, higher energy yield and superior oxidative stability which might cause less problems in fuel polymerisation during combustion (Knothe, 2012; Wood et al., 2015). Probably, these is a need to blend this algal oil with two (binary) or even more different microalgae oils to attain an optimum FAC for biodiesel production as suggested by Cha et al. (2011). On the other hand, the algal oil cultivated in diluted POME may have beneficial cold-flow properties with the increasing of unsaturation level.

\section{CONCLUSION}

POME was evaluated and found to be a potential medium in microalgae cultivation. The microalgae, Chlorella UMACC 283 cultivated in 5\% POME produced high content of lipid and biomass showing good potential as a biodiesel feedstock. It's good growth in POME contributed to the reduction of nutrients such as $\mathrm{PO}_{4}, \mathrm{NO}_{2}$ $\mathrm{NO}_{3}$ and COD which was important in wastewater treatment. In addition, the flat panel PBR showed better performing system in culturing Chlorella UMACC 283. The FAC of the algal lipid extracts showed an abundant of C16:0 and C18:0 with potential increase in unsaturation suitably used as a non-food type biodiesel feedstock.

\section{ACKNOWLEDGEMENT}

We would like to extend our appreciation to the Director-General of MPOB for permission to publish this article. 


\section{REFERENCES}

AZMI, N S and YUNOS, K F M (2014). Wastewater treatment of palm oil mill effluent (POME) by ultrafiltration membrane separation technique coupled with adsorption treatment as pre-treatment. Agriculture and Agricultural Science Procedia, 2: 257264.

BADAR, S N; YAAKOB, Z and TIMMIATI, S N (2017). Growth evaluation of microalgae isolated from palm oil mill effluent in synthetic media. Malaysian J. Analytical Science, 21: 82-94.

BRENNAN, L and OWENDE, P (2010). Biofuels from microalgae - A review of technologies for production, processing, and extractions of biofuels and co-products. Renewable and Sustainable Energy Reviews, 14: 557-577.

CHA, T S; CHEN, J W; GOH, E G; AZIZ, A and LOH, S H (2011). Differential regulation of fatty acid biosynthesis in two Chlorella species in response to nitrate treatments and the potential of binary blending microalgae oils for biodiesel application. Bioresource Technology, 102: 10633-10640.

CHEN, C Y; YEH, K L; AISYAH, R; LEE, D J and CHANG, J S (2011). Cultivation, photobioreactor design and harvesting of microalgae for biodiesel production: A critical review. Bioresource Technology, 102: $71-81$.

DALRYMPLE, O K; HALFHIDE, T; UDOM, I; GILLES, B; WOLAN, J; ZHANG, Q and ERGAS, $S$ (2013). Wastewater use in algae production for generation of renewable resources: A review and preliminary results. Aquatic Biosystems, 9.

ELMORAGHY, M and FARAG, H I (2014). In situ transesterification of Chlorella vulgaris towards biojet fuel production. Int. J. Engineering and Technical Research (IJETR), 2: 8-15.

GRIFFITHS, M J and HARRISON, S T L (2009). Lipid productivity as a key characteristic for choosing algal species for biodiesel production. J. Applied Phycology, 21: 493-507.

GUCCIONE, A; BIONDI, N; SAMPIETRO, G; RODOLFI, L; BASSI, N and TREDICI, M R (2014). Chlorella for protein and biofuels: From strain selection to outdoor cultivation in a green wall panel photobioreactor. Biotechnology for Biofuels, 7: 84.

HADIYANTO, H and NUR, M M A (2012). Potential of palm oil mill effluent (POME) as medium growth of Chlorella sp. for bioenergy production. Int. J. Environment and Bioenergy, 3: 67-74.
HADIYANTO, H; NUR, M M A and HARTANTO, G D (2012). Cultivation of Chlorella sp. as biofuel sources in palm oil mill effluent (POME). Int. J. Renewable Energy Development, 1: 45-49.

HANCSÓK, J; KRÁR, M; MAGYAR, S; BODA, L; HOLLÓ, A and KALLÓ, D (2007). Investigation of the production of high cetane number bio gas oil from pre-hydrogenated vegetable oils over Pt/ HZSM-22/Al2O3. Microporous and Mesoporous Materials, 101: 148-152.

HEMPEL, N; PETRICK, I and BEHRENDT, F (2012). Biomass productivity and productivity of fatty acids and amino acids of microalgae strains as key characteristics of suitability for biodiesel production. J. Applied Phycology, 24: 1407-1418.

HUERLIMANN, R; DE NYS, R and HEIMANN, K (2010). Growth, lipid content, productivity, and fatty acid composition of tropical microalgae for scale-up production. Biotechnol Bioeng, 107: 245-57.

ICHIHARA, K and FUKUBAYASHI, Y (2010). Preparation of fatty acid methyl esters for gas-liquid chromatography. J. Lipid Research, 51: 635-40.

IDRIS, N A; LOH, S K; LAU, H L N; MUSTAFA, E M; VELLO, V; TAN, C Y and PHANG, S M (2017). Cultivation of microalgae in medium containing palm oil mill effluent and its conversion into biofuel. J. Oil Palm Res. Vol. 29(2): 291-298.

JUNEJA, A; CEBALLOS, R and MURTHY, G (2013). Effects of environmental factors and nutrient availability on the biochemical composition of algae for biofuels production: A review. Energies, 6: 46074638 .

KAMYAB, H; DIN, M F M; KEYVANFAR, A; MAJID, M Z A; TALAIEKHOZANI, A; SHAFAGHAT, A; LEE, C T; SHIUN, L J and ISMAIL, H H (2015). Efficiency of microalgae Chlamydomonas on the removal of pollutants from palm oil mill effluent (POME). Energy Procedia, 75: 2400-2408.

KNOTHE, G (2012). Fuel properties of highly polyunsaturated fatty acid methyl esters. Prediction of fuel properties of algal biodiesel. Energy $\mathcal{E}$ Fuels, 26: 5265-5273.

LAMMENS, T M; FRANSSEN, M C R; SCOTT, E L and SANDERS, J P M (2012). Availability of proteinderived amino acids as feedstock for the production of bio-based chemicals. Biomass and Bioenergy, 44: 168-181.

LEE, O K; OH, Y-K and LEE, E Y (2015). Bioethanol production from carbohydrate-enriched residual 
biomass obtained after lipid extraction of Chlorella sp. KR-1. Bioresource Technology, 196: 22-27.

LOH, S K; LAI, M E; MUZZAMMIL, N; LIM, W S; CHOO, Y M; ZHANG, Z and SALIMON, J (2013). Zero discharge treatment technology of palm oil mill effluent. J. Oil Palm Res. Vol. 25: 273-281.

MATA, T M; MARTINS, A A and CAETANO, N S (2010). Microalgae for biodiesel production and other applications: a review. Renewable and Sustainable Energy Reviews, 14: 217-232.

MORENO-GARCIA, L; ADJALLÉ, K; BARNABÉ, S and RAGHAVAN, G S V (2017). Microalgae biomass production for a biorefinery system: Recent advances and the way towards sustainability. Renewable and Sustainable Energy Reviews, 76: 493-506.

MPOB (2016). Economics \& Industry Development Division. http: // bepi.mpob.gov.my/index.php/ en /, accessed on 3 March 2017.

MPOC (2013). Malaysian palm oil industry. http: / / www.mpoc.org.my/Malaysian Palm Oil Industry. aspx, accessed on 3 March 2017.

NARALA, R R; GARG, S; SHARMA, K K; THOMASHALL, S R; DEME, M; LI, Y and SCHENK, P M (2016). Comparison of microalgae cultivation in photobioreactor, open raceway pond, and a twostage hybrid system. Frontiers in Energy Research, 4.

NUR, M M A and HADIYANTO, H (2013). Utilization of wastewater as growth medium for microalgae based bioenergy feedtsock in Indonesia (an overview). Int. J. Sustainable Future for Human Security, 1.

NWUCHE, C (2014). Use of palm oil mill effluent as medium for cultivation of Chlorella sorokiniana. British Biotechnology J., 4: 305-316.
PRIBYL, P; CEPAK, V and ZACHLEDER, V (2012). Production of lipids in 10 strains of Chlorella and Parachlorella, and enhanced lipid productivity in Chlorella vulgaris. Applied Microbiology and Biotechnology, 94: 549-61.

RAI, U; DESHAR, G; RAI, B; BHATTARAI, K; DHAKAL, R P and RAI, S K (2014). Isolation and culture condition optimization of Chlorella vulgaris. Nepal J. Science and Technology, 14.

STRICKLAND, T R D and PARSON, T R (1972). A Practical Handbook of Seawater Analysis. $2^{\text {nd }}$ ed. Ottawa, Canada, Fisheries Research Board of Canada.

TAN, C Y; SULAIMAN, N M N; LOH, S K and PHANG, S M (2016). Chlorella biomass production in annular photobioreactor using palm oil mill effluent (POME): Effect of hydrodynamics and mass transfer, irradiance, aeration rate and POME concentration. J. Oil Palm Res. Vol. 28(4): 496-509.

VAIRAPPAN, C S and YEN, A M (2008). Palm oil mill effluent (POME) cultured marine microalgae as supplementary diet for rotifer culture. J. Applied Phycology, 20: 603-608.

VELLO, V; PHANG, S M; CHU, W L; MAJID, N A; LIM, P E and LOH, S K (2013). Lipid productivity and fatty acid composition-guided selection of Chlorella strains isolated from Malaysia for biodiesel production. J. Applied Phycology, 26: 1399-1413.

WANG, J; MAHMOOD, Q; QIU, J P; LI, Y S; CHANG, Y S and LI, X D (2015). Anaerobic treatment of palm oil mill effluent in pilot-scale anaerobic EGSB reactor. BioMed Research International, 2015: 1-7.

WOOD, B M; KIRWAN, K; MAGGS, S; MEREDITH, J and COLES, S R (2015). Study of combustion performance of biodiesel for potential application in motorsport. J. Cleaner Production, 93: 167-173. 